\title{
ENVIRONMENTAL AND SOCIAL SUSTAINABILITY INDEX (ESSI)
}

\begin{abstract}
Amna Faisal $^{1}$, Bahadir Tunaboylu ${ }^{2}$ Ismail Koyuncu $^{3}$
Keywords: MDG's (Millennium Development Goals), SDG's (Sustainable Development Goals), Yale University's Environmental performance index, SPI (Social Progress Index), LDC (Least developing country).

ABSTRACT: Sustainable development and globalization are becoming important subjects for policy makers to formulate the worldwide strategies and rubrics for ensuring simultaneous adoption of its components and monitoring of its consequences. Sustainable Development Goals (SDGs) published by United Nations are the guidelines to incorporate the assurance of sustainable development and its globalization. This study analyzes the sustainability from the perspective of not just the environment and the ecosystem of globe but also from the health and social aspects of humans. Indexes such as Environmental Performance Index (EPI) and Social progress Imperative (SPI) measure the performance of different countries based on the environment and the ecosystem by following Millennium Development Goals (MDGs) and social goals, separately. However, the parameters used in those indices have significant limitations. In this work, the proposed Environmental and Social Sustainability Index (ESSI) offers a new model whereby new relevant sustainability parameters including social progress indicators are used to measure the performance of countries based on SDGs by using reliable data from international organizations. Finally, countries are categorized according to sustainable development goals that highlight the importance and significance of each sustainability parameter especially for developing and under developed nations.
\end{abstract}

\section{Introduction}

In the modern era, sustainability is no longer just a subject of the environment or the ecosystem, it now implies a balanced combination of environmental health, ecosystem vitality and social order after the launch of Sustainable Development Goals (SDGs) in 2015 and it implies different

\footnotetext{
${ }^{1}$ Department of Industrial Engineering, Istanbul Sehir University, Turkey. IQTM, University of the Punjab, Pakistan. Email: amna.iqtm@pu.edu.pk.

2 Department of Industrial Engineering, Istanbul Sehir University, Turkey. Email: btunaboylu@sehir.edu.tr

3 Environmental Engineering Department, Istanbul Technical University, Turkey. Email: koyuncu@itu.edu.tr
} 
inferences for different societies. In reality, sustainability should include all abovementioned parameter with proper weightage to provide a balanced view. It should include the health of the land, water and air including the living organisms on them (UNDP, 2015). It is necessary to protect our natural environment, human and ecological health, while driving innovation and not compromising our way of life. (Jaehn, 2016). In the past, many indexes were formulated to measure the sustainability parameters, though some of the them are either outdated or not reliable in terms of data collection. Hence, the most prominent Environmental Performance Index (EPI)(Yale University, 2018), covering environmental health and ecosystem vitality, is consulted as the base for devising the proposed Environmental and Social Sustainability Index (ESSI). Meanwhile, Social Progress Imperative (SPI) was also analyzed to review the sustainability related parameters (Socialprogress, 2017). Hence this study encompasses the importance of sustainability not just related to ecology but also other pillar i.e. society.

\subsection{Literature Review}

\subsubsection{United Nations Sustainable Development Goals (SDGs)}

United Nations launched eight MDGs in 2000 that were valid up to 2015. However, after 2015, UN announced 17 new goals (SDGs) having targets for sustainability accompanying all pillars. It included 17 global goals, 169 targets and 230 indicators that apply to all countries, with the aim of achieving them by the year 2030 (European Commission, 2015). The SDGs are quite interrelated to MDGs and it is not wrong to affirm that SDGs are the advanced version of

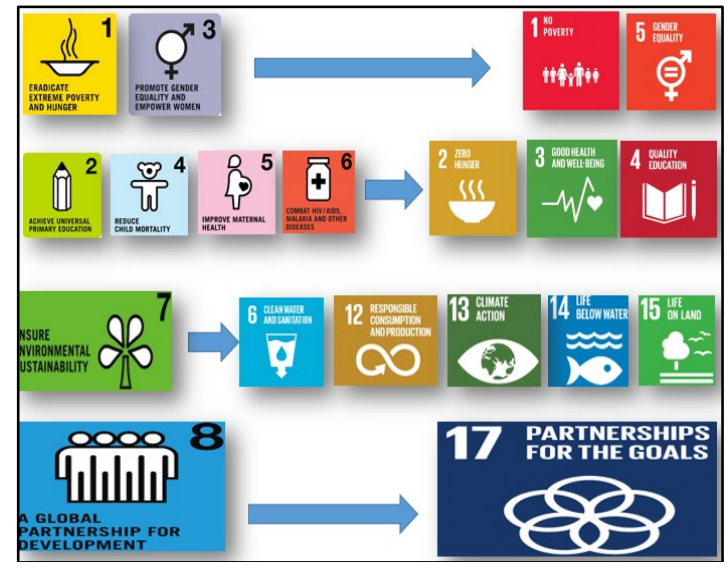

Figure 1 Conversion of MGDs to SGDs (Fukuda P., 2016)

MDGs. United Nations' symbols in Fig 1 (MDGs, 2000; UN SDGs, 2016) are 
used to show the transformation of MDGs to SDGs. This index has the agenda to focus on all SDGs by aiming entire targets through a range of indicators to measure sustainability scores of countries all over the globe. Some new sections were introduced in SDGs covering perspectives of justice and prosperity.

\subsubsection{EPI and Policy Objectives}

Yale University has been working on EPI since 2000 and they have launched more than 10 versions of this index. In EPI, 2018, they ranked 180 countries on 24 performance indicators according to 10 issues on policy categories of environmental health and ecosystem vitality (EPI, 2018). The index describes its indicators besides their abbreviations used to measure the parameter and allocation of factor wise weightage conferring their significance.

It provides a gauge to rank these countries on basis of performance among each other as well as their own previous performance. Therefore, it fallouts in a scorecard with numerals that shows ranking to indicate the overall performance of that country. This is how, it declares the high performers and laggards. It also provides a baseline for others to be leaders in sustainability. In their index, Yale University just focuses on MDG 7 that is "ensure environmental sustainability" but SDGs were not considered in their study (Yale University, 2018).

\subsubsection{Strengths and Weaknesses of Yale's EPI}

EPI used best available data from international research institutions, such as the Institute for Health Metrics and Evaluation, The World Resources Institute, and The Sea Around Us project at the University of British Columbia, together with international organizations such as the World Bank, World Health Organization and the UN Food and Agriculture Organization. Nevertheless, there are serious data gaps such as many countries do not have true data or some of them are not willing to share their database, which limits the capability of EPI to show fair results, and particularly it changes the performance of index in a number of important issues. Hence, availability of sufficient and reliable data on the agriculture, water resources, waste management, and threats to biodiversity and sustainability do strengthen the EPI (Hsu et al., 2013).

Moreover, in each version, they are improving but in the latest version they claimed to be aligned with internationally agreed SDGs by using quantitative approach to evaluate the policy performance and that, SDGs are baseline for their evaluation. In contrast, drawback is to declare developed countries as leaders and it might be expected. Yet, developing countries such as African countries are low performers, whose problems are beyond their abilities to 
sustain environmental, human and societal health. Hence, conclusions are derived from the index as a measuring tool and an advisory tool to policy makers. The statements such as from EPI findings: "Environmental performance is an issue of governance - only well-functioning governments are able to manage the environment for the benefit of all"(social watch, 2017). This is surprising since EPI does not include any governance factor that are even part of SDGs under Goal 16. They just have nine major issues (health, air quality, water and sanitation, water resources, agriculture, forests, fisheries, biodiversity and habitat, climate and energy).

Countries score between 0 and 100 in each area and then EPI can conclude that how close that country from the baseline. EPI focuses on the capacity to address a problem and not on the scale of the problem in each country or the background of that problem which may be the root cause of that issue. It ranks developing countries at the bottom and developed nations at the top. For instance, calculating wastewater treatment by giving it maximum weightage results veiling the fact that developed countries have those facilities while least developed do not, which results in declaring them as laggards. Therefore, irrespective of efforts and capacities of any country, it may not be fair to grade them under same circumstances. Conclusively, EPI conveys a message that Organization for Economic Cooperation and Development (OECD) countries are superlative and African countries are destructive for the globe. This problem can be overcome by adding some parameter on opportunity, growth, governance and economic related parameter in EPI (Roberto B., 2016).

\subsection{Aim and Objective of Study}

This study aims to analyze the sustainability performance of different countries comprised of complex set of variables where an integrated view of the environment and ecosystem with social aspects aligned with the SDGs. Existing indices EPI and SPI have concentrated on environmental performance and social order independently, because of this they have fundamental limitations. Another shortcoming is the absence of some emerging parameters in these indices. Thus, an integrated index including all critical environmental and social parameters aligned with Millennium Development Goals (MDGs) and SDGs with respect to sustainable development is needed. For this purpose, ESSI is developed which takes into account the most critical environmental and the ecosystem vitality indicators as well as key social progress parameters to reach an integrated model on sustainability. The study aims to identify all eminent parameters including new emerging 
parameters for a proposed new integrated index. The formulation of the index involves the computation of available data and respective weightage that yield the statistics of every factor. The index then enables forming a numeral ranking on a scorecard, presenting the sustainability performance of 180 countries based on two major factors; the environment and the society. The target is to analyze the performance of countries within a set of categories that includes observations of both ecological and societal parameters. This approach provides us with a new index that has an integrated view of sustainability.

\section{Methodology}

\subsection{Computation of proposed index}

ESSI aims to reinforce the global ranking by overcoming the entire dearth related to sustainability. For this, new categorical ranking is introduced in this proposed index keeping in view the United Nations' guidelines. With those categories, the performance of each country has been measured within its own group so that developed countries should not be only compared with developed ones. After grouping to define segments, the performance of each country has been ranked within its own group.

The 60 percent of ESSI has been generated from EPI as without a healthy environment, maintaining a prosperous and healthy life is at great risk. Climate change, pollution (air, water, solid) and ecosystem, all are important issues for human health. Thus, without considering these aspects, the well-being of the society is very difficult to achieve. If there is a struggle for survival, maintaining a better society is difficult. Nevertheless, social norms have their own importance, which cannot be ignored (Stronati, 2018). In ESSI, most important indicators for measuring social sustainability are the death rates, undernourishment, tolerance for immigrants and medical care.

EPI also does not include any parameter associated with the solid waste and noise. These subjects cannot be ignored, as solid waste is a great danger for air, soil, water and species on them especially when it is left untreated or treated improperly. For instance, leachates from dumps permeates in the soil and pollute the underground water. Dangerous situations arise when the solid waste is burnt without a well-defined procedure leaving harmful affects on air quality. One other consequence of this waste is noxious odor. Along with the damage to the environment, the solid waste is equally hazardous for human health too. It 
may originate numerous infections in humans as bacillary dysentery, diarrhea and amoebic dysentery, plague, salmonellosis, trichinosis, endemic typhus, cholera, jaundice, hepatitis, and gastro enteric diseases. (Sn \& Chadar, 2017).

Furthermore, the noise, which is not pleasant to the human ear. Environmental noise involves all uninvited sounds in our communities and even at workplaces. It is a great threat to environment and health. The noise pollution is becoming worse day by day and its magnitude is snowballing dramatically because of the rise in population, urbanization and usage of increasingly powerful and numerous vehicles. Increased number of highways, rails and air traffic is another cause. The effect to health cannot be ignored as the noise pollution has aggregate adversarial effects. It shrinks professional, domestic, communal and learning environments resulting in economic and social losses. It disturbs the sleep, concentration, recreation and communication (Goines \& Hagler, 2007).

\subsection{ESSI Policy Categories:}

This index is a proposed model to follow the SDGs by covering the policy categories shown in Table 1. A hierarchal framework is used to construct ESSI. Three main categories are divided into 8 parameters that further split the index into 42 indicators to measure the environmental and social sustainability of each country within the group of 180 countries. The constraint for assigning an indicator for each parameter of every policy category is to measure at least one angle of environment, ecosystem or social performance. Careful consideration is required for selection of indicators for environmental health and biome vitality, since both are thought to be very close to each other. This is the first version of ESSI and all indicators are included under the light of SDGs keeping in mind the limitation of data collection. However in the future, more indicators related to SDGs can be added into these 3 main policy categories of ESSI.

Table 1. Basic policy categories of ESSI

\begin{tabular}{|l|l|l|}
\hline Environmental Performance & $\begin{array}{l}\text { Ecosystem } \\
\text { Vitality }\end{array}$ & Social Order \\
\hline
\end{tabular}

\subsection{Parameter with Indicators and their Weightage in ESSI:}

As mentioned above, there are three main policy categories where environment and ecosystem is further classified into three parameter; 
Table 2. Parameter with indicators, their weightages and abbreviations in ESSI (EPI, 2018)

\begin{tabular}{|c|c|c|c|c|}
\hline $\begin{array}{c}\text { Policy } \\
\text { category }\end{array}$ & Parameter & $\mathbf{A b b}$ & Indicator & Abb \\
\hline \multirow[t]{2}{*}{$\begin{array}{l}\text { Environmental } \\
\text { Health \& } \\
\text { Ecosystem } \\
\text { Vitality } \\
(60 \%) \text {. } \\
\text { (Imported } \\
\text { from EPI) }\end{array}$} & $\begin{array}{l}\text { Environmental } \\
\text { Health(University, } \\
2018)(50 \%)\end{array}$ & EnH & $\begin{array}{l}\text { 1. Household Solid } \\
\text { Fuels }(40 \%) \\
\text { 2. } \mathrm{PM}_{2.5} \text { Exposure }(30 \%) \\
\text { 3. } \mathrm{PM}_{2.5} \text { Exceedance }(30 \%) \\
\text { 4. Drinking Water }(50 \%) \\
\text { 5. Sanitation }(50 \%)\end{array}$ & $\begin{array}{l}\text { HAD } \\
\text { PME } \\
\text { PMW } \\
\text { UWD } \\
\text { USD } \\
\text { PBD }\end{array}$ \\
\hline & $\begin{array}{l}\text { Ecosystem } \\
\text { Vitality(University, } \\
2018)(50 \%)\end{array}$ & $\mathrm{EcV}$ & $\begin{array}{l}\text { 1. Marine Protected } \\
\text { Areas }(20 \%) \\
\text { 2. } \begin{array}{l}\text { Biome Protection } \\
\text { (National) }(20 \%)\end{array} \\
\text { 3. } \text { Biome Protection } \\
\text { (Global) }(20 \%) \\
\text { 4. Representativeness } \\
\text { Index }(20 \%) \\
\text { 5. Species Habitat } \\
\text { Index }(10 \%) \\
\text { 6. Tree Cover Loss }(10 \%) \\
\text { 7. Fish Stock Status }(100 \%) \\
\text { 8. Regional Marine Trophic } \\
\text { Index }(50 \%) \\
\text { 9. CO Emissions } \\
\text {,Total }(50 \%) \\
\text { 10. CO } 2 \\
\text { Emissions,Power }(50 \%) \\
\text { 11. Methane Emissions }(20 \%) \\
\text { 12. } \mathrm{N}_{2} \mathrm{O} \text { Emissions }(20 \%) \\
\text { 13. Black Carbon } \\
\text { Emissions }(5 \%) \\
\text { 14. SO Emissions }(5 \%) \\
\text { 15. NOx Emissions }(50 \%) \\
\text { 16. Wastewater }\end{array}$ & $\begin{array}{c}\text { MPA } \\
\text { TBN } \\
\text { TBG } \\
\text { PAR } \\
\text { SHI } \\
\text { TCL } \\
\text { FSS } \\
\text { MTR } \\
\\
\text { DCT } \\
\text { DPT } \\
\text { DMT } \\
\text { DNT } \\
\text { DBT } \\
\\
\text { DST } \\
\text { DXT } \\
\text { WWT } \\
\text { SNM }\end{array}$ \\
\hline $\begin{array}{l}\text { Emerging } \\
\text { parameter not } \\
\text { included } \\
\text { inEPI.(10\%) }\end{array}$ & $\begin{array}{l}\text { Noise } \\
\text { Pollution(NationMast } \\
\text { er, 2014) and Solid } \\
\text { Waste(Bhada-Tata \& }\end{array}$ & EFE & $\begin{array}{l}\text { 1. Noise }(50 \%) \\
\text { 2. Solid waste management \& } \\
\text { recycling }(50 \%)\end{array}$ & $\begin{array}{l}\text { NOS } \\
\text { SWM }\end{array}$ \\
\hline
\end{tabular}




\begin{tabular}{|c|c|c|c|c|}
\hline \multirow{5}{*}{ 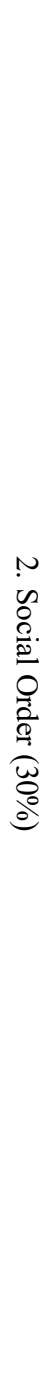 } & $\begin{array}{l}\text { Nutrition and Basic } \\
\text { Medical Care } \\
(20 \%)\end{array}$ & NBM & $\begin{array}{l}\text { 1. Undernourishment (B. S. } \\
\text { Stern \& Epner, 2018)(20\%) } \\
\text { 2. Depth of food deficit(S. } \\
\text { Stern, Wares, \& Epner, } \\
\text { 2017) }(20 \%) \\
\text { 3. Maternal mortality rate(B. S. } \\
\text { Stern \& Epner, 2018) }(20 \%) \\
\text { 4. Child mortality rate(B. S. } \\
\text { Stern \& Epner, 2018) }(20 \%) \\
\text { 5. Deaths from infectious } \\
\text { diseases (B. S. Stern \& }\end{array}$ & $\begin{array}{l}\text { UNN } \\
\text { DFC } \\
\text { MMR } \\
\text { CMR } \\
\text { DID }\end{array}$ \\
\hline & - Electricity $(15 \%)$ & ELC & $\begin{array}{l}\text { 1. Access (B. S. Stern \& Epner, } \\
2018)(50 \%) \\
\text { 2. Quality(B. S. Stern \& Epner, } \\
2018)(50 \%)\end{array}$ & $\begin{array}{l}\text { ATE } \\
\text { QOE }\end{array}$ \\
\hline & $\begin{array}{l}\text { - Access to Knowledge } \\
(15 \%)\end{array}$ & ATK & $\begin{array}{l}\text { 1. Adult literacy rate (B. S. } \\
\text { Stern \& Epner, 2018)(40\%) } \\
\text { 2. Primary and secondary } \\
\text { school enrollment (B. S. } \\
\text { Stern \& Epner, 2018)(30\%) } \\
\text { 3. Gender parity in education } \\
\text { (B. S. Stern \& Epner, }\end{array}$ & $\begin{array}{l}\text { ALR } \\
\text { PSE } \\
\text { GPE }\end{array}$ \\
\hline & - Opportunity(20\%) & OPP & $\begin{array}{l}\text { 1. Availability of affordable } \\
\text { housing(S. Stern et al., 2017) } \\
(40 \%) \\
\text { 2. Tolerance for immigrants(S. } \\
\text { Stern et al., 2017) }(40 \%) \\
\text { 3. Globally ranked } \\
\text { universities(B. S. Stern \& }\end{array}$ & $\begin{array}{c}\text { AAH } \\
\text { TFI } \\
\text { GRU }\end{array}$ \\
\hline & - Death Rate $(20 \%)$ & DeR & $\begin{array}{l}\text { 1. Traffic deaths (B. S. Stern \& } \\
\text { Epner, 2018)(25\%) } \\
\text { 2. Suicide rate (S. Stern et al., } \\
\text { 2017)(25\%) } \\
\text { 3. Premature deaths from non- } \\
\text { communicable diseases (B. S. } \\
\text { Stern \& Epner, 2018)(25\%) } \\
\text { 4. Life expectancy at } 60 \text { (B. S. } \\
\text { Stern \& Epner, 2018)(25\%) }\end{array}$ & $\begin{array}{l}\text { TDR } \\
\text { SDR } \\
\text { PDD } \\
\text { LER }\end{array}$ \\
\hline
\end{tabular}

Furthermore, the practice was to assign the weightages to these categories, their parameter and then their indicators to address the importance of each one.

environmental health, ecosystem vitality and some other emerging parameter. For the first two parameter, EPI is reviewed and the data is used as it is, unless there is new publicly available data on the category. However, the noise pollution and the solid waste are considered to enhance the reliability of this index. For the social order, we refer to SPI that contains more than 50 social parameter. Table 2. shows policy categories, their parameters, indicators 
accompanied by assigned weightages and references from where data are collected.

Moreover, abbreviations are used for these parameters to have individual identity. The indicators have been assigned for each parameter to measure the performance. It also shows the unit and procedure to measure that particular parameter.

\subsection{EPI Vs ESSI}

ESSI has major structural changes compared to EPI that distinguishes ESSI from other indexes in terms of sustainability pillars. For instance, environmental and ecosystem performance is considered by environmental health, ecosystem vitality, noise pollution and solid waste. While, EPI just unveiled the environmental health, ecosystem vitality. Despite the limitations of EPI, it is a worthy baseline and it is used for first two categories of ESSI due to its strength of data collection. Nevertheless, for other two parameter, the data is collected from World Bank (Bhada-Tata \& Wledge, 2012) and Nation Master (NationMaster, 2014). In EPI, the environmental health and the ecosystem vitality were given weightages as $40 \%$ and $60 \%$ respectively as mentioned by Yale University (EPI, 2018). Conversely, in ESSI this ratio has been changed to $50 \%, 50 \%$ as stated in Table 2. The environment and the ecosystem have been dealt as the total of $100 \%$, but in ESSI, $70 \%$ is assigned for them, from which $60 \%$ is for the environment and the ecosystem grades from EPI while $10 \%$ is assigned for the noise and the solid waste for proper representations of various contributors. The remaining 30\% has been assigned for social order and then, further division has been done as described in following paragraphs and illustrated in Table 2.

\subsection{SPI Vs ESSI:}

SPI measures the social progress of any country and it includes more than 50 indicators to display progress (Socialprogress, 2017). Therefore, SPI was used to extract the data for some particular parameter related to sustainability under the guidance of SDGs. Those parameter are mentioned above in Table 2 under the policy category of social order.

\subsection{Data Collection:}

As mentioned above, the data for certain categories from EPI is not altered and used as it is. Parameter taken to rank the social order are SPI driven. The sources mentioned by SPI are analyzed in detail for accuracy and assigned our own weightage to each indicator to get a final score. For the noise pollution, 
there is no data available for all countries across the globe by any of the renowned sources such as UN, WHO, and World Bank. Therefore, only one important aspect of the noise was considered for this category; the traffic noise that is most hazardous for the environmental sustainability and health of species on globe (Pirrera, De Valck, \& Cluydts, 2010). The data gathered from the number of cars for each country as cars/1000 person was used as the basis for noise analysis.

However, the noise levels are also strongly related to the driving behavior and horn-honking cultural differences of different societies. In developing and the least developed countries, there are workshops that replace car horns with a bus horn to create a louder noise. Taxi drivers are also notorious in horn honking in many such countries. There are no laws about horn honking in these countries which result in noise pollution despite fewer number of cars in the traffic on a car density basis (Jaffry. H, 2013). While in developed countries such as Spain, UK, USA and other European countries, horn honking is banned and may result in huge fines. Hence, people use horns very rarely just in case of emergency situations (L. John Smith, 2017). UN has classified countries all over the globe into four main countries according to their development (Frank, 2004). Therefore, we used that category to deal with each group to find out the traffic noise for each country. Hence, according to these facts and findings we assigned scores and code for each category described in Table 3.

Table 3. Groups classified by UN, horn-honking behavior score and color assigned to identify their group.

\begin{tabular}{|l|c|c|}
\hline Groups classified by UN & $\begin{array}{l}\text { Horn honking behaviar } \\
\text { score }\end{array}$ & Code given \\
\hline Developed countries & 0.2 & A \\
\hline Transitionary states & 0.4 & B \\
\hline Developing countries & 1 & C \\
\hline Least developed countries & 1 & D \\
\hline
\end{tabular}

\subsection{Formulation of index:}

The data is processed according to the weights described in Table 2. The index is calculated as the total of $100 \%$ and then all countries are being ranked according to their score from 100 . Indicators, for which data is processed in terms of 'points' $(0,1,2, \ldots)$ as in the case of globally ranked universities or quality of electricity then upper and lower values have been assigned to data range. On the other hand, for rest of cases, percentage of population (ppm) has 
been considered. Each indicator is contributing to one aspect of index and while calculating the score, to avoid unfair scoring and to reduce the impact of missing values, the constraint is followed as the country score will not be computed if more than one value from each factor is missing. The following formula is used to calculate the score for the index. The terminologies used in this formula are derived from Table 2.

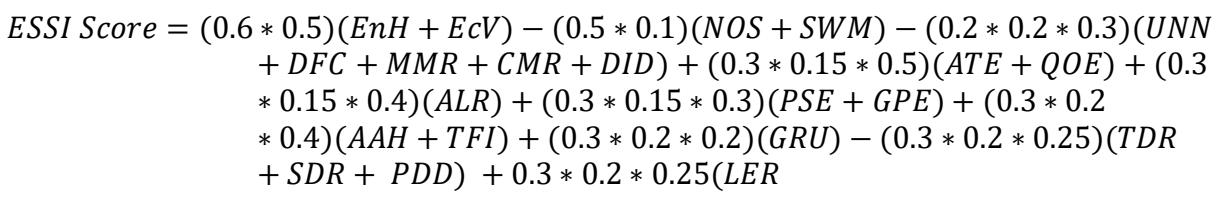

\section{Results and Discussion}

The data is processed by the above-mentioned formula for 180 countries and a scorecard is designed in the form of list as shown in Table 5 on next page having ESSI score and rank of each country.

It is clear from results that top 25 countries are developed nations while transitionary and developing states are somewhere in between and the least developed countries are at the end. The main reason behind this fact is the difference in policies, environment and activities for all groups. There are clusters in the results especially for highly developed and the least developed counties. All developed countries especially European countries use SDGs as the mentor and the guide for their environmental and social development. They started a project "Monitoring of the SDGs and the Europe 2020 strategy" and European Commission (Eurostat) follows the performance of EU strategies on a regular basis in the light of Sustainable Development Indicators (SDI). Three editions 2016, 2017, and 2018 have been published for this project.

Most of transitory states were part of Russia in the past and "Soviet Union era" damaged the environment of this zone. After 2012, however, President Medvedev issued an agenda containing the policy for environmental development until 2030. Therefore, all these countries are on the way to sustainability (Stiftung, 2016). It has been discussed earlier, that countries around the globe do not have the same resources, knowledge, opportunities and laws. Therefore, it may be unfair to rank them as a single large entity. Essentially, a monitoring framework is required by a global alliance among governments and scientific bodies for developing countries for required implementation and monitoring of SDGs. Devising metric is a core task for 
Table 5 indicates countries, their ESSI score and rank among other countries. Here R represents rank.

\begin{tabular}{|c|c|c|c|c|c|c|c|c|c|c|c|}
\hline $\mathbf{R}$ & Country & Score & Code & $\mathbf{R}$ & Country & Score & Code & $\mathbf{R}$ & Country & Score & Code \\
\hline & Switzerland & 83.5 & A & 30 & Colombia & 67.5 & $\mathrm{C}$ & 59 & Belarus & 60.5 & B \\
\hline & France & 83.2 & A & 31 & Singapore & 67.4 & $\mathrm{C}$ & 60 & Chile & 60.3 & $\mathrm{C}$ \\
\hline & Finland & 80.6 & A & 32 & Slovakia & 67.0 & A & 61 & Turkey & 60.3 & $\mathrm{C}$ \\
\hline & Denmark & 80.4 & A & 33 & Israel & 66.9 & $\mathrm{C}$ & 62 & Brazil & 60.1 & $\mathrm{C}$ \\
\hline & UK & 80.3 & $\mathrm{~A}$ & 34 & Estonia & 66.9 & A & 63 & Taiwan & 60.0 & $\mathrm{C}$ \\
\hline & Spain & 79.9 & $\mathrm{~A}$ & 35 & Lithuania & 66.4 & A & 64 & Azerbaijan & 59.9 & B \\
\hline 7 & Sweden & 79.8 & A & 36 & Bulgaria & 66.3 & A & 65 & Serbia & 59.8 & B \\
\hline & Malta & 79.0 & A & 37 & Croatia & 65.5 & A & 66 & Bahamas & 59.3 & $\mathrm{C}$ \\
\hline & Japan & 78.4 & A & 38 & Latvia & 65.5 & A & 67 & Egypt & 59.1 & $\mathrm{C}$ \\
\hline 10 & Belgium & 78.1 & A & 39 & Cuba & 65.4 & $\mathrm{C}$ & 68 & Iran & 58.8 & $\mathrm{C}$ \\
\hline 11 & Luxemburg & 78.0 & A & 40 & Tunisia & 65.4 & $\mathrm{C}$ & 69 & El Salvador & 58.2 & $\mathrm{C}$ \\
\hline 12 & Ireland & 78.0 & A & 41 & Romania & 65.1 & A & 70 & Maldives & 57.9 & $\mathrm{C}$ \\
\hline 13 & Austria & 78.0 & A & 42 & Peru & 64.3 & $\mathrm{C}$ & 71 & Georgia & 57.8 & B \\
\hline 14 & Iceland & 77.7 & $\mathrm{~A}$ & 43 & Hungary & 63.9 & A & 72 & Algeria & 57.7 & $\mathrm{C}$ \\
\hline 15 & Norway & 77.6 & A & 44 & Uruguay & 63.7 & $\mathrm{C}$ & 73 & Nicaragua & 57.6 & $\mathrm{C}$ \\
\hline 16 & Germany & 76.9 & $\mathrm{~A}$ & 45 & Sri Lanka & 63.2 & $\mathrm{C}$ & 75 & Jamaica & 57.2 & $\mathrm{C}$ \\
\hline 17 & Netherlands & 76.2 & A & 46 & Ecuador & 63.0 & $\mathrm{C}$ & 76 & Guatemala & 57.0 & $\mathrm{C}$ \\
\hline 18 & Australia & 76.1 & A & 47 & Venezuela & 63.0 & $\mathrm{C}$ & 77 & Kazakhstan & 57.0 & B \\
\hline 19 & Greece & 76.0 & A & 48 & Panama & 62.9 & $\mathrm{C}$ & 78 & Mauritius & 57.0 & $\mathrm{C}$ \\
\hline 20 & Canada & 76.0 & A & 49 & Morocco & 62.8 & $\mathrm{C}$ & 79 & Mexico & 56.8 & $\mathrm{C}$ \\
\hline 21 & Italy & 75.2 & A & 50 & Armenia & 62.6 & B & 80 & Kyrgyzstan & 56.7 & B \\
\hline 22 & New Zealand & 75.1 & A & 51 & Montenegro & 62.1 & $\begin{array}{l}\text { B } \\
\text { D }\end{array}$ & 81 & Cabo Verde & 55.8 & $\mathrm{C}$ \\
\hline 23 & Portugal & 74.8 & $\mathrm{~A}$ & 52 & Poland & 61.9 & A & 82 & St. Vincent & 55.8 & $\mathrm{C}$ \\
\hline 24 & United States & 73.6 & A & 53 & Seychelles & 61.7 & $\mathrm{C}$ & 83 & Bolivia & 55.7 & $\mathrm{C}$ \\
\hline 25 & Cyprus & 72.2 & A & 54 & Russia & 61.5 & B & 84 & Ukraine & 55.6 & B \\
\hline 26 & Costa Rica & 68.6 & $\mathrm{C}$ & 55 & Turkmenistan & 61.3 & B & 85 & Barbados & 55.4 & $\mathrm{C}$ \\
\hline 27 & Albania & 68.2 & B & 56 & Jordan & 60.9 & $\mathrm{C}$ & 86 & Philippines & 55.4 & $\mathrm{C}$ \\
\hline 28 & Czech Republic & 68.0 & $\mathrm{~A}$ & 57 & Macedonia & 60.6 & B & 87 & Antigu ard Barbuda & 55.2 & $\mathrm{C}$ \\
\hline 29 & Slovenia & 67.7 & $\mathrm{~A}$ & 58 & Dominican Republic & 60.6 & $\mathrm{C}$ & 88 & South Korea & 55.1 & $\mathrm{C}$ \\
\hline
\end{tabular}




\begin{tabular}{|c|c|c|c|c|c|c|c|c|c|c|c|}
\hline $\mathbf{R}$ & Country & Score & Code & $\mathbf{R}$ & Country & Score & Code & $\mathbf{R}$ & Country & Score & Code \\
\hline 89 & Argentina & 54.9 & $\mathrm{C}$ & 120 & Ghana & 45.5 & $\mathrm{C}$ & 151 & Bangladesh & 35.4 & D \\
\hline 90 & Qatar & 54.9 & $\mathrm{C}$ & 121 & Namibia & 45.4 & C & 152 & Guinea & 34.9 & D \\
\hline 91 & Paraguay & 54.8 & $\mathrm{C}$ & 122 & Myanmar & 45.4 & D & 153 & Nepal & 34.7 & D \\
\hline 92 & Saudi Arabia & 54.6 & $\mathrm{C}$ & 123 & Bahrain & 45.1 & $\mathrm{C}$ & 154 & Côte d'Ivoire & 34.5 & $\mathrm{C}$ \\
\hline 93 & Tonga & 54.6 & $\mathrm{C}$ & 124 & Sudan & 44.7 & D & 155 & Vanuatu & 34.2 & D \\
\hline 94 & Sac Tone and Princige & 54.6 & D & 125 & Gabon & 44.6 & $\mathrm{C}$ & 156 & Cameroon & 34.1 & $\mathrm{C}$ \\
\hline 95 & Moldova & 54.6 & B & 126 & Comoros & 44.6 & D & 157 & Angola & 33.7 & D \\
\hline 96 & Samoa & 54.5 & D & 127 & Brunei & 44.6 & C & 158 & Pakistan & 33.5 & $\mathrm{C}$ \\
\hline 97 & Trinidad Tobago & 54.4 & $\mathrm{C}$ & 128 & Kenya & 44.5 & C & 159 & Burkina Faso & 33.4 & D \\
\hline 98 & China & 54.2 & $\mathrm{C}$ & 129 & Guyana & 43.7 & $\mathrm{C}$ & 160 & Zambia & 33.3 & D \\
\hline 99 & St. Lucia & 53.7 & $\mathrm{C}$ & 130 & Cambodia & 43.1 & D & 161 & Botswana & 33.2 & $\mathrm{C}$ \\
\hline 100 & Oman & 53.4 & $\mathrm{C}$ & 131 & Senegal & 43.1 & $\mathrm{D}$ & 162 & Benin & 33.1 & D \\
\hline 101 & Lebanon & 52.8 & $\mathrm{C}$ & 132 & Rep of. Congo & 42.8 & $\mathrm{C}$ & 163 & Liberia & 32.7 & $\mathrm{D}$ \\
\hline 102 & Thailand & 52.6 & $\mathrm{C}$ & 133 & Iraq & 42.6 & $\mathrm{C}$ & 164 & Solom on Islands & 32.2 & $\mathrm{D}$ \\
\hline 103 & Vietnam & 52.3 & $\mathrm{C}$ & 134 & Fiji & 42.3 & $\mathrm{C}$ & 165 & Chad & 31.4 & D \\
\hline 104 & Bosnia & 52.2 & B & 135 & Gambia, The & 41.7 & D & 166 & India & 31.4 & $\mathrm{C}$ \\
\hline 105 & UAE & 51.8 & $\mathrm{C}$ & 136 & Micronesia & 41.1 & $\mathrm{C}$ & 167 & Eritrea & 30.3 & $\mathrm{D}$ \\
\hline 106 & Honduras & 51.6 & $\mathrm{C}$ & 137 & Tanzania & 40.4 & D & 168 & Niger & 29.3 & D \\
\hline 107 & Grenada & 51.5 & $\mathrm{C}$ & 138 & Laos & 40.4 & $\mathrm{C}$ & 169 & Sierra Leone & 29.3 & D \\
\hline 108 & Uzbekistan & 51.2 & B & 139 & Rwanda & 40.3 & $\mathrm{D}$ & 170 & Swaziland & 29.2 & $\mathrm{C}$ \\
\hline 109 & Mongolia & 51.0 & $\mathrm{C}$ & 140 & Malawi & 40.0 & D & 171 & Guinea-Bissau & 28.5 & D \\
\hline 110 & Malaysia & 51.0 & $\mathrm{C}$ & 141 & Mauritania & 39.2 & D & 172 & Madagascar & 26.8 & D \\
\hline 111 & Guinea & 50.6 & D & 142 & Niger & 38.9 & $\mathrm{D}$ & 173 & Zimbabwe & 26.7 & $\mathrm{C}$ \\
\hline 112 & Bhutan & 50.3 & D & 143 & Mali & 38.4 & D & 174 & Papas New Grinea & 25.8 & C \\
\hline 113 & Suriname & 49.8 & $\mathrm{C}$ & 144 & Djibouti & 37.8 & $\mathrm{D}$ & 175 & Congo, Den. Reg - of & 24.5 & D \\
\hline 114 & Nigeria & 48.1 & $\mathrm{C}$ & 145 & Kiribati & 37.3 & D & 176 & Haiti & 24.5 & D \\
\hline 115 & Libya & 48.1 & $\mathrm{C}$ & 146 & Ethiopia & 37.1 & D & 177 & Burundi & 23.5 & $\mathrm{D}$ \\
\hline 116 & Timor-Leste & 48.0 & D & 147 & South Africa & 36.4 & C & 178 & Afghanistan & 23.2 & D \\
\hline 117 & Tajikistan & 47.0 & B & 148 & Mozambique & 36.3 & D & 179 & Lesotho & 18.1 & D \\
\hline 118 & Kuwait & 46.8 & $\mathrm{C}$ & 149 & Togo & 35.7 & D & 180 & Central & 5.7 & D \\
\hline 119 & Indonesia & 45.5 & $\mathrm{C}$ & 150 & Uganda & 35.7 & $\mathrm{D}$ & & & & \\
\hline
\end{tabular}

SDGs implementation so, there should be a mechanism to assign parameters and ensured tracking. While selecting the indicators, keeping an eye is vital to make the progress beneficial in many ways. In developing nations, in some 
cases, there is no proper communication and information is fragmented which results in data gaps and inaccurate results. Another important cause of inability is the absence of policies related to the infrastructure, database management system, lack of skilled work force and high-performance computing. There is no standardization and data verification at initial stage of this process. As a result, it ends up with poor decision-making (Sarvajayakesavalu, 2015).

Awkwardly, most of least developed countries are lying after the second half in this ranking. It has been discussed earlier, that least developed and highly developed countries do not have same resources, knowledge, opportunities and laws. Therefore, it will be quite unfair to rank them in a single pipeline. According to UN categories, results have been refined to find out leaders and laggards in their respective groups.Fig 2 illustrates countries' ESSI scores on World map.

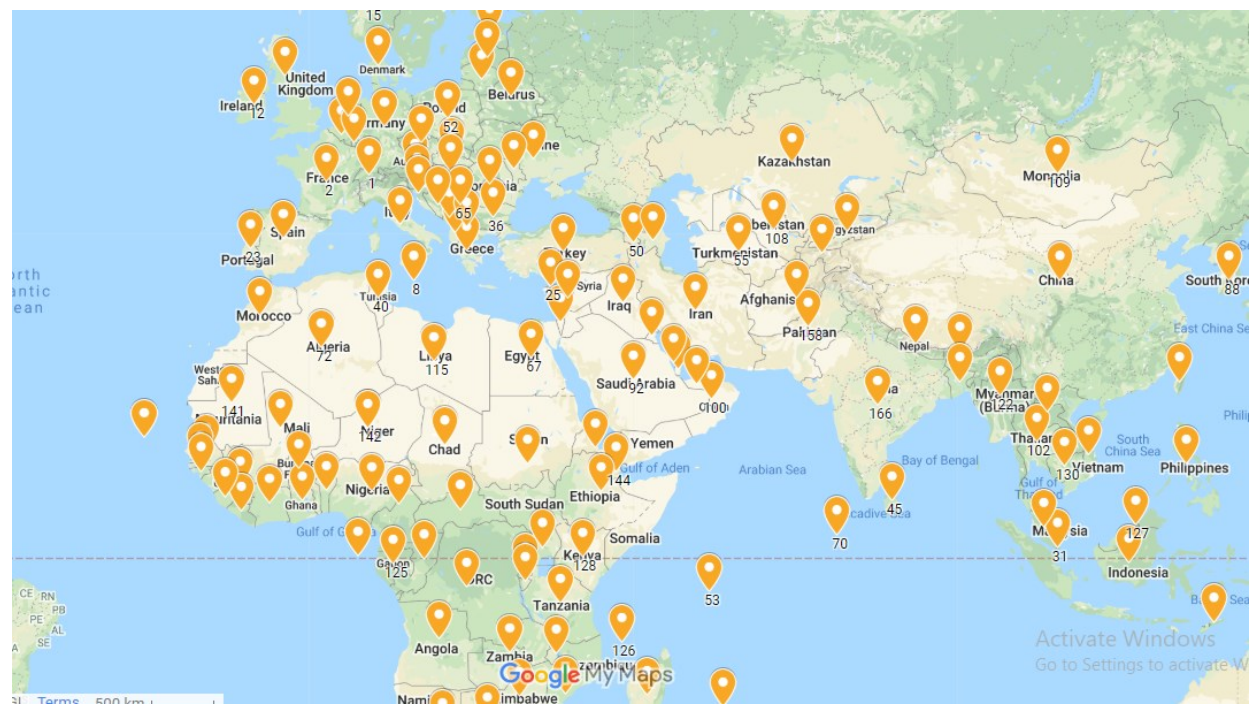

Figure 1 Illustrates Countries' ranks on World map.

After comparisons of all countries in Table 5, another viewpoint is to analyze them group wise and it is the comparison of intra group entities rather than inter group comparison. By looking at the score of each country in contrast of others within same category for highly developed and transitory nations, it can be commented that they are very similar. However, LDCs and developing countries are considered here as mostly they appear to have the same economic, social and environmental conditions within their own groups. Extinction of 
poverty in LDCs is most challenging goal among SDGs where almost fifty percent population lives below the poverty line. UNCTAD (United Nations Conference on Trade and Development) contends that LDCs are battlefield for winning or losing SDGs. In "Istanbul Programme of Action", achievement of 7 percent annual growth rate is suggested as a baseline for LDCs for attaining SDGs. Outside circumstances and forces can have strong influences on the organizations in LDCs in terms of GDP growth. However, government of these countries can follow durable policies to reduce the impact of these external forces. (UNCTAD, 2018).

To check the efficiency of ESSI, a comparison has been conducted for 180 countries among EPI and ESSI score. The main purpose of this comparison is to highlight the differences among the environmental and social performance of countries. The results are obvious for least developed countries as they have a score change of \pm 10 points. They occupy the last places in both indexes but swapped the positions with each other. Transitory states shows improvements in their ranks because of projects like "Local Initiatives (Microfinance) Project II". It helps these states to enhance their infrastructures to follow SDGs (Badema D., 2005). Turkey turns out to be one of the improving nations in ESSI compared to EPI. It jumps from 158 (EPI) rank to $61^{\text {st }}$ position in ESSI. There are important parameter behind this improvement but one of the main reason is the "Series of Project (SOP)" that lend money to (Iller Bank) to provide money to selected municipalities for improving the public services all over the country. This program stands on private-public investment with a target of maximizing finance for development, aligned with social sustainability at national and international level (World Bank, 2018).

\section{Conclusion:}

SDGs are carrying out a role as an important guide for all developed, transitory, developing and the least developed countries. This study provides first version of ESSI, which highlights the performance of 180 countries with respect to SDGs. All the columns of sustainability are important and ESSI measures the performance of these countries within the boundaries of sustainability. It measures this within the limitations of LDCs problems and deficiencies and addresses the dominance of developed states. It addresses the environmental sustainability ranking by adding social parameter that take into account capabilities and efforts of countries in a more integrated vision of sustainability. All parameter represented in ESSI have importance, purpose and connection with SDGs. More contributing parameter related to the environment, 
ecosystem and social order could potentially be added in ESSI to improve its capability further.

The new index offers a new model of social progress and environmental factors based on SDGs. It provides a more complete picture of sustainability in the world by using reliable data from international organizations. The outcomes are clear; developed nations are leaders while the least developed ones are laggards. Our results based on this new index shows significant ranking difference of countries from previous indices because of better-integrated formulation of relevant parameters.

This study illustrates the reasons behind the high scores of developed states as well as details of developing and low rank for least developed countries. These countries are then classified into UN categories to rank them in their own groups to overcome the limitation of different resources, policies and opportunities. A comparison has been carried out for each group to find out the leader and laggard in that group. Lastly, ESSI score has been compared to EPI score to find out if a country performs very well according to EPI, but not as good for social order.

\section{References:}

1. Badema D. (2005). Sustainable Development in Bosnia and Herzegovina. Retrieved from

http://webcache.googleusercontent.com/search?q=cache:http://kurs.uib.no/geografi -online/302/papers/dizdar.doc

2. Bhada-Tata, D. H. and P., \& Wledge. (2012). Solid Waste, What a Waste 2012 World fact sheet. Wold Bank.

3. EPI, Y. U. (2018). Yale University variables names. Retrieved from https://epi.envirocenter.yale.edu/downloads/epi2018variablenamesv07.xlsx

4. European Commission. (2015). The 2030 Agenda for Sustainable Development and SDGs - Environment - European Commission. Retrieved from http://ec.europa.eu/environment/sustainable-development/SDGs/index_en.htm

5. Frank, V. (2004). Country Classification by UN. World Bank Report, Msc.

6. Fukuda P. (2016). From the Millennium Development Goals to the Sustainable Development Goals. Gender \& Development, 24(1), 43-52.

7. Goines, L., \& Hagler, L. (2007). Noise Pollution: A Modern Plague. Southern Medical Journal, 100(3), 287-294.

8. Hsu, A., Sherbinin, A. De, Johnson, L., Hawkins, N., Schwab, F., \& Stahl, S. (2013). Retrieved from http://epi.yale.edu/content/measuring-progress-practical-guidedevelopers-environmental-performance-index-epi

9. Jaehn, F. (2016). Sustainable Operations. European Journal of Operational Research, 253(2), 243-264. 
10. Jaffry. H. (2013). Transportation In The Developing World (Third World) | Facts and Details. Retrieved October 24, 2018, from http://factsanddetails.com/world/cat57/sub382/item2140.html\#chapter-9

11. L. John Smith. (2017). Driver WARNING - honking car horn can land you $£ 1,000$ fine | Express.co.uk. Retrieved October 26, 2018, from https://www.express.co.uk/life-style/cars/809642/driving-law-honking-car-hornUK-fine

12. MDGs, U. (2000). United Nations News Centre. Retrieved November 3, 2018, from www.un.org/apps/news/infocus/UNdecoded/UNdecoded.asp?NewsID=1330\&sID $=48$

13. NationMaster. (2014). All countries compared for Transport \&gt; Road \&gt; Motor vehicles per 1000 people. Retrieved from http://www.nationmaster.com/countryinfo/stats/Transport/Road/Motor-vehicles-per-1000-people

14. Pirrera, S., De Valck, E., \& Cluydts, R. (2010). Nocturnal road traffic noise: A review on its assessment and consequences. Environment International, 36(5), 492-498.

15. Roberto B. (2016). Environmental Performance Index greenwashes the rich Global Policy Watch. Retrieved May 23, 2018, from www.globalpolicywatch.org/blog/2016/05/09/.

16. Sarvajayakesavalu, S. (2015). Addressing challenges of developing countries in implementing five priorities for sustainable development goals. Ecosystem Health and Sustainability, 1(7), art24-art24.

17. Sn, C., \& Chadar, K. (2017). Solid waste pollution : a hazard to environment. Recent Advances in Petrochemical Science (RAPSCI), 2(3), 2-4. Retrieved from https://juniperpublishers.com/rapsci/pdf/RAPSCI.MS.ID.555586.pdf

18. Social watch. (2017). criticism on Yale EPI. Retrieved June 5, 2018, from http://www.socialwatch.org/fr/node/17303

19. Socialprogress. (2017). 2017 Social Progress Index. Retrieved June 1, 2018, from https://www.socialprogressindex.com/?tab=4

20. Stern, B. S., \& Epner, T. (2018). Social! Progress! Index! Methodology! Summary! Retrieved from www.socialprogress.org

21. Stern, S., Wares, A., \& Epner, T. (2017). Social Progress Index 2017. Methodology Report.

Retrievedfromhttps://www.socialprogressindex.com/assets/downloads/resources/e n/English-2017-Social-Progress-Index-Findings-Report_embargo-d-until-June-212017.pdf

22. Stiftung, B. (2016). Country Reports. Retrieved October 28, 2018, from https://www.bti-project.org/en/country-reports/

23. Stronati, D. (2018). Social sustainability vs environmental sustainability. Which matters most? | Institution of Civil Engineers. Retrieved October 28, 2018, from https://www.ice.org.uk/news-and-insight/the-civil-engineer/june-2018/social-vsenvironmental-sustainability

24. UN SDGs. (2016). Sustainable Development Goals symbols. Retrieved November 3 , 2018 ,

from 
https://www.un.org/sustainabledevelopment/blog/2015/12/sustainabledevelopment-goals-kick-off-with-start-of-new-year/

25. UNCTAD. (2018). Achieving the sustainable development goals in the least developed countries.

26. UNDP. (2015). Sustainable Development Goals | UNDP. Retrieved from http://www.undp.org/content/undp/en/home/sustainable-development-goals.html

27. University, Y. (2018). 2018 EPI Results. Retrieved from https://epi.envirocenter.yale.edu/epi-topline
28. World Bank.
(2018).

Turkey

Overview. http://www.worldbank.org/en/country/turkey/overview\#3

29. Yale University. (2018). Introduction | Environmental Performance Index. New York. Retrieved from https://epi.envirocenter.yale.edu/2018-epireport/introduction

C) 2020 by the authors. Licensee UAIC, Iasi, Romania. This article is an open access article distributed under the terms and conditions of the Creative Commons Attribution (CC BY-NC-ND) license (https:// creativecommons.org/licenses/by-nc-nd/4.0). 